work on the freshwater fishes of the U.S.S.R. and neighbouring countries, a third edition of which appeared in 1932-33, will long remain a standard work, invaluable to all students of Palæarctic fishes. Dr. Berg, who was born in 1876, is still actively engaged in his work, and his many friends and coworkers will wish him many more years of fruitful labour in ichthyology.

\section{Mr. S. Hazzledine Warren}

THERE is a special propriety in the award by the Geological Society of the Prestwich Medal to Mr. S. Hazzledine Warren. The ground of the award, as officially stated, is "in recognition of his researches on the geology and archæology of East Anglia, particularly in the Lea Valley" ; but without detracting in any degree from the value and importance of his original researches and discoveries in this area, it is placed to his credit by archæologists that his severely critical attitude of mind on every point of evidence bearing on the antiquity, character, and condition of flint implements, and the natural or artificial origin of their fractures, has conduced to sanity in that study of the earliest evidence of man's handiwork, with which the name of Sir Joseph Prestwich has been associated from the earliest days when the discovery of 'eoliths' was first proclaimed. Throughout the whole of his long and distinguished career as a prehistoric archæologist, Mr. Warren has devoted himself indefatigably to the close scientific examination of such questions as patination, modes of fracture under varying conditions, and other matters depending upon the physical properties of flint, with the view of determining their evidential value as clues in the technology of antiquity; and if he has not always been able to go all the way with his fellow workers, it has been recognized that his conservatism has always advanced knowledge in a real sense and not retarded it. Of Mr. Warren's investigations in the field, posterity will perhaps be most indebted to him for his discovery of the Graig Lwyd factory site, significant for the light it throws on prehistoric economics, and his exploration of the Clactonian industry, which has had so profound an effect on all subsequent study of palæolithic cultures.

\section{Pre-Crag Implements}

A communication has been issued by Mr. J. Reid Moir recapitulating his arguments rebutting the criticisms of his claim for the human origin of the pre-Crag 'implements' discovered in, or derivative from, Pliocene deposits in East Anglia. It has been argued from their physical condition and the high angle of flaking that not only were these flaked flints produced by natural forces, but also that in actual fact they are such as could not have been produced, or if produced, used for their supposed purpose, by man. This, it is claimed, has been shown by experiment. To this Mr. Reid Moir replies, pointing out that the flaking of certain, and especially the older classes of pre-Crag implement could not have been produced by the forces responsible for the striations they exhibit, as these score a post-flaking patination ; while the argument from the steepness of the angle of flaking-apparent in some instances only-and the inability of the modern critic to reproduce typical specimens applies equally to certain types of palæolithic implement, of which the authenticity is unquestionable. It has, however, been found possible to imitate high angle flaking experimentally, and the product is also a practicable tool for working wood and bone. Mr. Reid Moir classifies pre-Crag implements into five groups, which differ in age and in character of flaking. "Is it to be supposed," he pertinently asks, "that nature varied her methods of flaking flints five times in the Pliocene epoch ?" Finally, as the result of many years' study devoted to the examination of later deposits, he asserts that never has he discovered a flint fashioned in situ which bears any resemblance to a pre-Crag implement, as might be expected were such flaking attributable to natural forces. At the same time it is to be remembered, he points out, that rostrocarinates have now been found in many parts of the world from Palestine to Java, where glacial conditions and solifluxion could not have operated to produce them.

\section{Social Relations of Science}

Correspondence has passed between the British Association and the Parliamentary Science Committee concerning the possibility of a working liaison between the Association's new division for the Social and International Relations of Science and the Parliamentary Science Committee. At a recent meeting of the latter body it was decided to invite Sir Richard Gregory, in his capacity as chairman of committee of the new division, to accept co-option to the Executive Committee of the Parliamentary Science Committee, and this invitation has now been accepted by Sir Richard. Normally the Parliamentary Science Committee confines co-option to its executive to members of one of the Houses of Parliament. It was felt, however, that in this instance it was particularly desirable to make an exception in favour of the chairman of this newly formed division of the British Association. It was a fitting compliment on another ground, for, as the erstwhile chairman of the British Science Guild (now merged in the British Association), Sir Richard was intimately associated with the formation of the Parliamentary Science Committee. Indeed, had it not been for other preoccupations at the time, he would have been a member of the Committee from its inception.

\section{Survey of Nyasaland Food Resources}

A comprehensive nutritional survey, under the leadership of Dr. B. S. Platt, the first of its kind to be undertaken in the British Colonial Empire, is now being carried out in Nyasaland with the object of studying the actual and potential food resources of three contrasting areas. This survey is the outcome of a recommendation made by the Committee of the Economic Advisory Council on Nutrition in the Colonial Empire. Dr. B. S. Platt has been appointed to the staff of the Medical Research Council for five years to organize and co-ordinate, with the assistance 